\title{
General Paralysis Still Occurs
}

David Rice, Consultant Psychiatrist, HM Prison Service, Brian Vawdrey, Consultant Psychiatrist, Graylingwell Hospital, Chichester, and Tim Bushell, Consultant in Genito-Urinary Medicine, Royal West Sussex Hospital, Chichester

Florid cases of GPI of the classical type described in the older text books do not nowadays commonly occur. There must be many psychiatrists who have never had the opportunity of seeing such a patient and it is for this reason that this case history is detailed.

A man of $\mathbf{4 2}$ was received in a prison hospital in May 1981 with a query from the Magistrates as to his fitness to plead. Physical examination was essentially negative and the only history of illness or injury was of a broken nose from boxing in adolescence, haemorrhoids 14 years before and gonorrhoea treated 10 years previously.

At interview he was cheerful and friendly with slight slurring of speech. When addressed by name he said that was not his real name, and said that he was going to be World Heavyweight Champion this year. He spoke of teaching Steve Davis to play snooker and of how he had just sold a black stallion to Josh Gifford, the trainer, for $£ 3,000,000$.

He denied any previous illness except gonorrhoea, which he said he had had 15 years ago (he specifically denied syphilis), claimed his brother was a barrister and that he himself was married with three children, all well, and that he had given them each a million pounds. He described himself as a millionaire, said he owned a local town and spoke of going round the country selling black stallions.

A provisional diagnosis of GPI was made and blood and CSF were sent to the laboratory. A report was made to the Magistrates' Court saying he was unfit to attend Court or to plead, and that investigations were proceeding. The laboratory results were as follows: (i) $C S F-62$ cells (mainly lymphocytes), Protein $1.2 \mathrm{~g} /$; Glucose $2.5 \mathrm{mmol} / \mathrm{l}$; TPHA Positive 1280; VDRL Positive (neat only); FTA (Abs) 1gG = Positive $1 \mathrm{gM}$-Negative; (ii) Blood-VDRL Positive 1/2, TPHA Positive $1 / 1200+$, FTA (Abs) $1 \mathrm{gG}=$ Positive $1 \mathrm{gM}$ Negative.

Four days after admission a friend visited and gave most helpful background information. He had known the patient and his family for years and said that he was one of four children. He had been married, but separated for nine years. As a young man he had been 'a bit of a boy', keen on all sports, especially boxing and snooker, and had suffered several minor head injuries. Until the last two or three months, he had been a smart man and, at one time, a doorman at a night club and heavy drinker. The friend volunteered that he had become depressed about 15 months previously and that it was a few months later that his flat became neglected and dirty and he had himself lost his smartness. About two months before arrest he had become noisy, talkative, grandiose and elated and for a month or so had been extravagant and expansive and his talk had become strange and difficult to follow.

For several days he remained disturbed-he tried to set fire to his cell and required sedation-but as soon as the laboratory confirmed the diagnosis, treatment with Crystapen 1 million units $(500,000$ units b.d. for 15 days) was started. He quietened rapidly, but remained expansive and full of well-being. Two weeks after originally seen he was still far from well but was able to admit that he had 'had a dose' 15 years before from which he said he was cured with two tablets. His ex-wife was contacted and the position explained. Her GP was also informed and asked to check the wife and children. All proved negative.

By the middle of the year he was vastly improved. He was no longer noisy at night and kept himself clean and tidy. He ate his meals in an ordinary way and was able to talk sensibly about himself. He said he had served as a merchant seaman and that he had had 'girls in every port'; although grandiose delusional ideas remained, he was able to recall some of his more extravagant ideas as 'my dreams'.

A second course of Crystapen was begun and a report made to the Court that he was still in need of treatment, preferably in hospital, and that the nature of his illness meant that he was unlikely ever to recall events leading up to his Court appearance or to be able to instruct solicitors or Counsel about them. It was felt also that he had been too seriously ill when he came in for it to be likely that he was fully responsible for whatever offences constituted the charge. The police indicated that they were prepared to drop the charge and arrangements for his admission to hospital were put in hand.

He was transferred two months after his first remand following an appearance in Court when no evidence was offered. CSF examination, taken a week before, showed Treponema Haemagglutination Positive 1280, VDRL slide test positive 1 in 2, Fluorescent Treponemal Antibody (Abs) lgG Positive 1gM Weak Positive. This man clearly had primary syphilis 15 or so years ago, possibly at the same time as the gonorrhoea, did not receive adequate treatment and presented as a patient with classical GPI at the age of $\mathbf{4 2 .}$

He was duly accepted into the ordinary admission ward on transfer from prison, and re-examined five days after admission. He was pleasant and co-operative, but at times mildly confused. By this time the majority of the grandiose delusions reported above had disappeared, but he still described himself as the Number One snooker player in the locality, and claimed to have beaten Steve Davis.

The next incident of note occurred a week later when he absconded from the open ward and 'streaked' naked in the town as a result of auditory hallucinations of unidentified voices telling him that unless he did this he would die. The latter voices soon receded and he was referred to a consultant (TB) the following month. By this time he had caused considerable trouble by absconding on at least 10 occasions 
overnight, before either returning on his own accord or being brought back by the police.

Clinically he showed mild signs of organic dementia and was at times auditorily hallucinated and aggressive without provocation, e.g. knocking a cigarette out of a woman patient's hand. It was consequently decided to transfer him to the semi-closed male ward. Here, unfortunately, his habit of rummaging in other patients' lockers, and his confusion, upset some of the more aggressive patients and for his own safety transfer back to the admission ward became necessary and thence, when a bed became available, to a long-term male ward.

He had been seen by a consultant neurologist who commented that it had been some 20 years since he had seen a case of GPI. He found that the patient's pupils were small and irregular but just reacted to light and accommodation. His speech was markedly slurred and dysarthric, but no other abnormal CNS signs were elicited. Although he had already had two separate fortnights of Benzyl Penicillin b.d. following which had had improved markedly, it was felt that two further prolonged courses of Benzathine Penicillin would be appropriate in order to be certain of achieving continuous treponemicidal serum levels of penicillin. He was accordingly given Benzathine Penicillin 1.2 mega units every four days for 28 days; this was repeated after a month's interval.

Apart from the anti-syphilitic treatment described, psychotropic medication was initially mainly trifluoperazine with depixol $100 \mathrm{mg}$ IM three-weekly during a mildly paranoid phase, and amitriptyline when depressed. Lumbar puncture at this stage suggested cure of the treponemal infection with cells and protein having returned to normal (WBC $1 \times 10^{\circ} / 1$, Protein $0.35 \mathrm{~g} / \mathrm{l}$ ), although the VDPL was still positive at 1.8 (reference laboratory). Despite apparent cure of his infection, clinical deterioration has occurred-a well recognized problem. The nature of any possible progressive cerebral pathology is unknown.

From the psychiatric point of view the prognosis will presumably be that of a slowly progressive organic dementia. It seems unlikely that the florid grandiose delusions will recur, although the auditory hallucinations will probably do so.

\section{An Historical Vignette: Surrealism and Anti-Psychiatry}

This open letter/manifesto to medical directors of lunatic asylums appeared 60 years ago in La Révolution Surréaliste (Vol 1, No 3, p. 29, April 15, 1925). The editors, Pierre Naville and Benjamin Péret, later became founding members of the IVth (Trotskyist) International. It is likely that the main author was the leader of the French Surrealist group, Andre Breton. [Translated from French by Dr Petr Skrabanek and Dr Richard Walsh.]

\section{SIRS}

Law and custom grant you the right to measure the mind. It is with your understanding that you exercise this sovereign and fearsome jurisdiction. We have to laugh. The gullibility of civilized nations, of scholars, and of rulers bedecks psychiatry with god-knows-what supernatural illuminations. The trial of your profession is decided in advance. We do not intend to discuss here the worth of your science nor the dubious existence of mental diseases. But for a hundred pretentious pathogeneses, in which the confusion of matter and mind is unleashed, for a hundred classifications of which the most vague are yet the only usable ones, how many highminded attempts are made to come near to the cerebral world in which your prisoners live? How many of you, for example, are there for whom the dream of the schizophrenic, the images to which he is a prey, are anything but a word-salad?

It does not surprise us to find you unequal to a task for which only few are predestined. But we rise up against the right accorded to some men, limited or not, to sanction their investigations in the realm of the mind by perpetual

\section{imprisonment.}

And what imprisonment! It is known-but not widely enough-that the asylums far from being asylums are dreadful gaols, where the inmates provide free and convenient labour, and where ill-treatment is the rule - this you tolerate. The lunatic asylum, under the camouflage of science and justice, is comparable to the barracks, the prison, the penitentiary.

We do not wish to raise here the question of arbitrary internments, to save you the trouble of facile denials. We declare that a large number of your lodgers, perfectly mad according to the official definition, are no less arbitrarily interned. We do not accept that anyone may hinder the free blossoming of a person in delirium, something which is as legitimate and as logical as any other sequence of ideas or of human acts. The repression of antisocial reactions is as illusory as it is unacceptable in principle. All individual acts are antisocial. The madmen are the individual victims par excellence of social dictatorship; in the name of that individuality which is the mark of man, we demand that these convicts of sensitivity be set free-since it is not in the power of law to imprison all men who think and act.

Without emphasizing the utterly brilliant nature of what is manifest in certain madmen, as far as we are to understand it, we declare the absolute legitimacy of their concept of reality and of all the acts which derive from it.

Would you kindly remember this tomorrow morning at the ward-round when you try to converse, without the necessary vocabulary, with these men over whom-be it known to you-you have no superiority but that of force. 